\title{
ChIAPAS: LA GUERRILLA QUE QUERÍAMOS
}

\author{
Chiapas: the Guerrilla that We Wanted
}

\author{
Marcos Cueva-Perus
}

Resumen: En este texto me propongo mostrar cómo la representación de la insurrección armada chiapaneca de 1994 del Ejército Zapatista de Liberación Nacional fue moldeada a partir de ese año no por su dinámica interna, sino por un sector de la intelectualidad de izquierday por la sociedad civil mexicanas, que crearon un imaginario de los rebeldes como indígenas no contaminados por la modernidad que vivían en un estado "natural". Al no ser esto cierto, los intelectuales simpatizantes pudieron integrarse al grupo armado, pero no definir su política y práctica de una manera adecuada. Sin embargo, los principios y la formación política sobrevivieron en el grupo armado chiapaneco.

Palabras clave: indígenas, neozapatismo, Ejército Zapatista de Liberación Nacional (Chiapas, México), guerrilla.

Abstract: This paper attempts to show how the representation of the 1994 armed uprising in Chiapas by the Ejército Zapatista de Liberación Nacional was molded from that year forward, not by internal dynamics but by a sector of the intellectual left and by the Mexican civil society. That not being the case, sympathetic intellectuals could join the armed group, but were unable to define politics and practice in a manner that adequately captured the sense of the movement. Regardless, the political stance and formation survived in the armed group in Chiapas.

Keywords: neozapatism, indigenous, Ejército Zapatista de Liberación Nacional (Chiapas, México), guerrilla.

Marcos Cueva Perus, doctor por la Universidad Pierre MendésFrance de Grenoble II, Francia. Investigador titular en el Instituto de Investigaciones Sociales de la Universidad Nacional Autónoma de México. Temas de especialización: historia de las ideas, historia de las mentalidades en América Latina y el Caribe. Correo electrónico: cuevaperus@yahoo.com.mx.
Enviado a dictamen: 20 de noviembre de 2015 Aprobación: 10 de febrero de 2016.

Revisiones: 2. 


\section{Introducción}

E ste texto no es sobre el Ejército Zapatista de Liberación Nacional (EZLN) ni sobre el subcomandante Marcos en Chiapas, ni sobre el discurso de ninguno de ellos, aunque incluso por momentos el del segundo haya pretendido ser el del primero o haya sido interpretado en todo caso de este modo —el "dar voz a quienes no la tienen"— más allá de Chiapas y en las muchas entrevistas que quisieron "dar la vuelta al mundo". Éste es un artículo que se detiene en la reacción de una parte de la intelectualidad mexicana e internacional - éste es el objeto de estudio privilegiado - ante una guerrilla que, para aquélla, acabó siendo supuestamente original en comparación con los focos armados de antaño. Lo fue sin duda por tratarse de un movimiento armado que se orientó muy pronto a la negociación y a las reivindicaciones de los pueblos indios, algo que sin embargo no ocurría en un principio en el EZLN, en enero de 1994. En este texto se muestra que ese vuelco paulatino del movimiento armado se produjo en cierta medida a partir del momento en que, en lugar del Estado o el pueblo mexicanos, al correr de los años noventa la guerrilla comenzó a buscar entre sus principales interlocutores a los intelectuales - aunque no fueran "analistas profesionales", pues prácticamente no los hubo al carecerse con frecuencia de análisis, salvo excepciones a posteriori- considerados de izquierda y a una sociedad civil de contornos difusos, aunque en un principio lo suficientemente claros y presentes para proteger al EZLN y evitar un desenlace militar.

Pareciera que la historia de esta guerrilla fue escrita por el subcomandante Marcos, prolífico. Con todo, este texto muestra cómo fueron los intelectuales mencionados y parte de esa sociedad civil — que no es el pueblo- quienes establecieron los términos en que esa historia habría de escribirse - lo que no quiere decir que "practicarse" - y para qué público - hasta cierto punto, esa historia habría de escribirse para ellos mismos en la supuesta cultura y no en las cuestiones políticas propiamente dichas, según veremos-, con cierta comodidad de "hacerse servir en la selva", incluso al margen de la realidad de la evolución del EZLN, en vez de hurgar en la incómoda, temida o despreciada — por dizque "teórica" — soledad del escritorio. Hay una distancia entre el eco que tuvo el movimiento armado en determinados sectores intelectuales y la indiferencia con la que fue recibido en buena parte de la sociedad mexicana, salvo en un principio. Precisemos que estas líneas no significan que el movimiento haya sido infructuoso en una práctica que no hemos ignorado, como demostramos al final de nuestro texto: incluso aquél fue fructífero tal vez "pese a" la "mediación", la supuesta "interlocución” y la fascinación de una parte del mundo intelectual.

Lo que debiera llamar la atención es que pasadas dos décadas sus saldos prácticamente no fueron objeto de análisis detallado entre buena parte de la intelectualidad mencionada, entre otras cosas porque la práctica neozapatista no interesó demasiado a parte de esa intelectualidad, como lo prueba a nuestro juicio entre los "expertos" o "analistas profesionales" el muy frecuente olvido de la Otra Campaña de 2006, a raíz de la Sexta Declaración de la Selva Lacandona. El análisis desde el punto de vista de las ciencias sociales fue justamente lo que se extravió más pronto entre esa intelectualidad, y lo que curiosamente la mayoría de los intelectuales de izquierda y parte de la sociedad civil prefirieron dejar de lado, para privilegiar —ellos - "ensayos" entendidos como derecho a cualquier "reflexión subjetiva" — la "opinión"-, "testimonios" — la supuesta "reflexión subjetiva" de los "subalternos" que curiosamente ya no aparecían en 2006 - y hasta "ocurrencias", muchas de las cuales no están disponibles en la web y hay que recordarlas para entrar en la indagación hemerográfica. Así, fue aprovechado en beneficio de la intelectualidad y de parte de la sociedad civil el hecho de que, como lo mencionaran Xóchitl Leyva y Willibald Sonnleitner, confluyeran en el neozapatismo - a diferencia del "zapatismo" descriptivo de Neil Harvey (2000: 209), llamado así por convención y para diferenciarlo del zapatismo de la época revolucionaria - una "pluralidad de intereses, voluntades e identidades [...] dentro de un campo de contradicciones y tensiones no resueltas", como fue aprovechado que el neozapatismo, lejos de ser monolítico y homogéneo, fuera multifacético, polisémico y fluídico (Leyva y Sonnleitner, 2000: 165). 
Aquí nos hemos ocupado de una de esas "voluntades" y de un aspecto de esa polisemia. El ensayo se acerca al género literario y aquí, en el estudio científico, que es algo distinto, el uso de un criterio individual - con el debate de categorías de análisis, no con retóricano puede interpretarse como una "afrenta subjetiva" aunque "original" a una "cientificidad" que quisiera ser única, salvo que deba renunciarse a ese criterio - aceptando un desplazamiento sistemático de los objetos de estudio hacia ésta, destinado a desbaratar toda individualidad y elección propias-y simplemente buscar la glosa y el formato único estándar. Nietzsche, White y Rousseau aparecen aquí en la argumentación en la medida en que el objeto de estudio no es el discurso del EZLN, reiteremos, sino el discurso de una parte de la intelectualidad sobre aquél, para "moldearlo" y "formatearlo" ante la "opinión pública" — confundida por lo demás con la propia intelectualidad-, de tal modo que los clichés intelectuales permanecieran intactos y se pudieran reproducir. Por lo demás, insistamos: si hay demérito, no es a grandes rasgos para la guerrilla y tiene más bien que ver con el modo en que fue recibida entre algunos de sus interlocutores, lo cual, repetimos, es nuestro principal objeto de estudio.

Años de ardua labor política —documentada por diversos autores, como Antonio García de León (EZLN, 2000: 11-29) y Carlos Tello Díaz (1995), no como fuente única- desembocaron en la conversión del movimiento armado, después de 1994, en "natural" —es nuestra segunda hipótesis-, lo que desde luego no era, mucho menos durante una larga fase preparatoria. Una guerrilla que en un principio quiso ser política se convirtió en lo que algunos llamarían "narrativa": el subcomandante Marcos entró en ésta, haciendo partícipe al EZLN, "en espejo" de la imagen tanto del indígena, como del guerrillero, que podía resultar la anhelada para otros. Raras veces los movimientos armados han conservado a "sus" intelectuales en América Latina. No pocos intelectuales se distanciaron de la Revolución cubana y otros tantos lo hicieron del sandinismo, desencantados. Aquí buscamos observar que no hubo, en cambio, distanciamiento entre los intelectuales, poco interesados en las prácticas neozapatistas y "su" guerrilla chiapaneca, desde el momento en que el EZLN resultó ser, en una parte del discurso, hasta cierto punto la imagen complaciente, y naturalizada, de los sectores mencionados.

Nos apoyaremos aquí finalmente en algunas reflexiones de Roger Bartra sobre lo que podríamos llamar "la construcción de la imagen del salvaje" para mostrar lo ocurrido entre parte de la intelectualidad, la "sociedad civil" y "su" guerrilla mediante una "narrativa" específica hecha para que la intelectualidad que así lo quisiera encontrara en el EZLN y su líder aquello que deseaba, y no alguna alteridad real.

\section{El inicio y el vuelco: el año 1994}

En los primeros días de enero de 1994, la acción delEZLN no parece haber sido nada virtual, aunque a los pocos meses, según veremos en este apartado, se acomodara en buena parte del discurso - no forzosamente en la práctica- a imaginarios discursivos citadinos y de ciertos segmentos sociales. Baste mencionar por lo pronto que un integrante de la guerrilla, entrevistado en Ocosingo, declaraba: "el socialismo es la única vía para terminar con este sistema donde hay ricos que comen tranquilamente sentados en su mesa, mientras los campesinos andan pelando los lomos y no tienen nada" (Pérez, 1994: 7). Hasta el cese al fuego de una decena de días después del lo de enero de ese año, hubo combates y acciones armadas en San Cristóbal de Las Casas, Las Margaritas, Ocosingo, Altamirano y Chanal, ataques a instalaciones militares - Rancho Nuevo, cuartel general de la XXXI Zona Militar, cuartel militar de San Cristóbal de Las Casas-, la captura del general Absalón Castellanos y varios muertos. Los comunicados del EZLN mostraban desde el 2 de enero, fecha de la Primera Declaración de la Selva Lacandona (EZLN, 2000: 33-35), a un grupo armado listo para la guerra: hablaba de prisioneros, juicios sumarios y avance de tropas incluso hasta la capital mexicana, y estaba deseoso de ser reconocido como fuerza beligerante, lo que fue explícitamente solicitado. Desde diciembre de 1993, según un órgano de la guerrilla —El despertador mexicano-, se preparó una campaña que incluía desde 
el cobro de impuestos de guerra, hasta la promulgación de nuevas leyes para ser adicionadas a la Constitución mexicana, como una Ley Agraria Revolucionaria, una Ley Revolucionaria de Mujeres, una Ley de Reforma Urbana, una Ley del Trabajo, una Ley de Industria y Comercio, una Ley de Seguridad Social y una Ley de Justicia (EZLN, 2000: 36-48). Difícilmente puede pensarse de todo lo anterior que no haya sido más que blofeo. La guerrilla que veía así la luz aspiraba a tener alcance nacional. Un poco más adelante, ya con el presidente Ernesto Zedillo en el Gobierno mexicano, se producirá un conato de enfrentamiento armado. Sin embargo, el grueso de la acción armada, de alcance muy limitado, no llegó ni a la quincena de días.

Aquí consideramos que el quiebre más importante en la orientación del EZLN se produjo en el "Aguascalientes" de Guadalupe Tepeyac. Todavía había aquí una propuesta política: el grupo armado sugería un gobierno de transición democrática, una Constituyente y una nueva Constitución que incorporara figuras como el plebiscito y el referéndum popular (EZLN, 2000: 296-298). Antes, a principios del conflicto armado, el EZLN había generado cierto conocimiento sobre la situación socioeconómica de Chiapas en un documento histórico analítico - "El Sureste en dos vientos, una tormenta y una profecía” (EZLN, 2000: 49-66) —, algo que llama la atención, dado el desconocimiento de Chiapas en la sociedad mexicana. Sin embargo, ya en la Convención Nacional del "Aguascalientes" chiapaneco la atmósfera no era exactamente popular, sino resultado de la confluencia de la intelectualidad de izquierda y buena parte de la llamada "sociedad civil". Elena Poniatowska le había preguntado al subcomandante Marcos, de acuerdo con una entrevista rastreable vía hemerográfica y no en la web: “iPor qué le hacen tanta ilusión los intelectuales? Es que son líderes de opinión, había contestado aquél. ¿Pero cuál es su fuerza? Inquirió nuevamente la escritora. Esa misma, inciden en la opinión pública, en la sociedad civil, replicó el subcomandante Marcos" (Poniatowska, 1994: 18).

A partir de ahí, pese al poder de convocatoria entre ciertos sectores, buena parte de la sociedad mexicana se volvió ausente, lo que, según mencionamos al final de este texto, no quiere decir que el EZLN se haya vuelto simple espectáculo. Con todo, la presidencia de esa magna convención estuvo compuesta de "celebridades" del mundo intelectual, sin que mencionarlas como tales implique negarles mérito. "Es en la sociedad civil en quien reside nuestra soberanía", había decidido para entonces la Segunda Declaración de la Selva Lacandona (EZLN, 2000: 270), seguramente por el entusiasmo con que previamente muchas organizaciones no gubernamentales habían protegido al EZLN, según lo hace constar, por ejemplo, Neil Harvey al recordar, entre otros, los papeles jugados por la Caravana de Caravanas y el Espacio Civil por la Paz, lo que llevó en un momento al EZLN a decir "no" al diálogo con el Gobierno y a preferir el que podía establecerse con la sociedad civil (Harvey, 2000: 214). En efecto, todavía a comienzos de 1994, el EZLN agradecía a estas organizaciones que se habían "[...] convertido, a juicio del grupo armado, en parte fundamental del movimiento para una paz digna" porque veía en ellas, un tanto curiosamente:

[...] el futuro al que [aspiramos]. Un futuro en el que la sociedad civil, con su fuerza de justicia verdadera, haga innecesarias no sólo las guerras sino también los ejércitos, y un futuro en el que los gobiernos, cualesquiera que sea su tendencia política, tenga por encima de ellos la vigilancia constante y severa de una sociedad civil libre y democrática (EZLN, 2000: 162).

¿Confundió el EZLN la sociedad civil con las organizaciones no gubernamentales? Esta sociedad civil, según Monsiváis, en el campo de la izquierda y el centro izquierda, era un amasijo de buenas intenciones y grandes recuerdos: los días del terremoto, el 88, las pequeñas y grandes conquistas. Hoy, en gran medida debido a la fe que el EZ - para ellos autoridad moral y visión externa- deposita en la "sociedad civil", "quienes sienten integrarla creen de veras en sus alcances y las comillas van desapareciendo", proseguía el cronista (EZLN, 2000: 315). A partir de 1999, aunque el tono del EZLN era menos "sectario", según Monsiváis, que el de la Primera Declaración de la Selva Lacandona: 
[...] se proyecta(ban) alianzas con la sociedad civil, con intelectuales y artistas, con sectores de izquierda, con grupos de marginados. En todos estos casos el éxito es muy relativo porque no hay hábito de discusión teórica. Con frecuencia los planteamientos de Marcos son intrépidos y estimulantes pero de sus interlocutores suele obtener respuestas emocionales y lugares comunes (EZLN, 2003: 19-20).

Al entrevistar a Marcos en el "Aguascalientes", Elena Poniatowska le había preguntado: "ipero la sociedad civil está preparada para plantear sus problemas?" (Poniatowska, 1994: 13). Para Adolfo Gilly, fue la "sociedad civil" la que "adoptó y protegió" al EZLN (1998: 85). Héctor Díaz Polanco consideró, por su parte, que el EZLN se dirigía a una "sociedad civil" de contornos vagos:

[...] es posible cavilar que a menudo se tienen expectativas desorbitadas respecto del comportamiento de la sociedad civil. Debido a su propia amplitud y heterogeneidad, la sociedad civil no puede ser un ente en perpetua movilización y tensión, preparado para actuar como un solo cuerpo en todo momento. Son muy diversos los intereses, las visiones, las preocupaciones que bullen en su seno, y su organización es mínima, cuando no inexistente (Díaz Polanco, 2006: 143).

No hay nada que sea "naturalmente de izquierda" y se enalteció entonces lo que carecía de organización, aparente al menos, como si la "sociedad civil" fuera espontánea. Escribe Monsiváis en su crónica del "Aguascalientes":

La plenaria continúa con discursos y saludos. De pronto, el estallido. Se abate la tormenta y todos se congregan bajo la lona. Lo que sigue es a la vez terrible y magnífico, soberbio y patético. El ruido de la lluvia amenaza y encandila, y si en Woodstock la muchedumbre lanzó gritos encantatorios [sic] para detener la naturaleza (no rain! No rain!), aquí las consignas hacen las veces de sortilegios. Sigue la precipitación pluvial y un grupo resiste con exorcismos históricos: iZapata vive! (coro) !La lucha sigue! iZapata vive y vive! Si Zapata viviera (coro) icon nosotros estuviera! (EZLN, 2000: 322).

El otro símil, más allá del establecido con Woodstock, es con el navío de Fitzcarraldo (EZLN, 2000: 317). Ya hay espectáculo. Si algo llama la atención en las crónicas más difundidas de esta convención es que quienes asisten hablan de sí mismos, pero muy poco o nada acerca de los indígenas o de Chiapas, como si el evento hubiera podido tener lugar en cualquier otra parte.

A partir de aquí, quien "lleva" a la organización armada no es ni siquiera el subcomandante Marcos, sino una parte de intelectualidad deseosa de una "guerrilla dionisíaca”, según veremos. Monsiváis alcanza a hacerse una pregunta clave: ¿desde dónde se habla y para quién? (EZLN, 2003: 14).

Para Marcos sí hay tal cosa como la mente de la sociedad, entidad homogénea y heterogénea en grado sumo, integrada por inercias y vislumbres. ¿A qué "mente de la sociedad" se dirigen sus textos? A la dispuesta a conversar con el punto de vista de la disidencia a la que se le atribuyen lucidez y radicalismo. Hasta cierto punto, Marcos está seguro: sus escritos expresan a su comunidad. Digo hasta cierto punto porque, también, cada escrito refiere el proceso de un autor que conversa, pelea, revisa su arsenal teórico, aspira a la comprensión global. Su interlocutor ideal está a la vista: inteligente, de izquierda (es decir, preocupado centralmente por la desigualdad social), muy crítico, lector de literatura (y por lo mismo al tanto de alusiones, homenajes y autohomenajes), habituado al idioma de los símbolos, con sentido del humor centrado en la paradoja y las descripciones del ridículo de los poderosos, habituado a ejercer la sorna, la ironía, el choteo (EZLN, 2003: 14).

Diríase que no está claro si Monsiváis habla del subcomandante Marcos o de sí mismo, pero lo cierto de esta observación es que el segundo se dirige a un "segmento" muy focalizado de la sociedad mexicana. 
¿Es Marcos quién lo ha escogido o es este segmento el que ha escogido a la que cree que es "su" guerrilla y a su principal protagonista?

Dos elementos coinciden para hacer del EZLN lo que hemos llamado, con propósitos analíticos, una guerrilla "dionisíaca". Por un lado, es posible encontrar en escritos de varios intelectuales la celebración de una guerrilla pacífica que es a la vez "auténtica" y que parece ser tan natural como la naturaleza. Por otra parte, a partir de cierto momento los comunicados del EZLN y las palabras de Marcos se empeñan en mostrar esta misma naturalidad, la de algo que "ha brotado" no por organización, ni formación política ni militar, ni por años de esfuerzo, sino por una "rebeldía" casi espontánea e igualmente equiparable al desencadenamiento de las fuerzas de la naturaleza. En esta "naturaleza" - que hace aparecer como igualmente espontánea a la sociedad civil - se pierde finalmente todo análisis político de estructura y de coyuntura, toda evaluación del curso de la guerrilla, y sobre todo de su lugar en la sociedad mexicana. Lo que señalamos aquí y que se encuentra entre otros en Nietzsche es una visión de "la vida" que no atribuimos al EZLN ni tampoco al subcomandante Marcos. Es la visión que poco a poco parece ir teniendo parte de la intelectualidad mexicana sobre el movimiento armado y lo que éste significa, una especie de "vuelta a las raíces" que suele ser parte de una simbología que esa misma intelectualidad está lejos de desdeñar, desde las imágenes de Zapata y Villa hasta la de Frida Kahlo.

\section{La guerrilla dionisíaca}

Este elogio de la naturaleza está en la figura dionisíaca que hace Nietzsche. Es el del estado primaveral y en la bebida narcótica: "en ambos estados, considera Nietzsche, el principium individuationis (principio de individuación) queda roto, lo subjetivo desaparece totalmente ante la eruptiva violencia de lo generalhumano, más aún, de lo universal-natural" (Nietzsche, 2010: 195). Puede parecer extraño atribuirle algo así a un movimiento armado que propone el encuentro de "todos", pero aquí nos referimos a una intelectualidad para la cual, de repente, lo humano y lo natural se fusionan. Después de todo, según Nietzsche:

[...] las fiestas de Dionisio no sólo establecen un pacto entre los hombres, también reconcilian al ser humano con la naturaleza. De manera espontánea ofrece la tierra sus dones, pacíficamente se acercan los animales más salvajes: panteras y tigres arrastran el carro, adornado con flores, de Dionisio. Todas las delimitaciones de casta que la necesidad y la arbitrariedad han establecido entre los seres humanos desaparecen: el esclavo es hombre libre, el noble y el de humilde cuna se unen para formar los mismos coros báquicos. En muchedumbres cada vez mayores va rodando de un lugar a otro el evangelio de la "armonía de los mundos": cantando y bailando se manifiesta el ser humano como miembro de una comunidad superior, más ideal; ha desaprendido a andar y a hablar. Más aún, se siente mágicamente transformado, y en realidad se ha convertido en otra cosa. Al igual que los animales hablan y la tierra da leche y miel, también en él resuena algo sobrenatural. Se siente dios, todo lo que vivía sólo en su imaginación, ahora eso él lo percibe en sí” (Nietzsche, 2010: 195).

No parece ser la intelectualidad aludida la que hace el coro al neozapatismo, menos aún cuando esta intelectualidad siempre se reserva para sí "la crítica". Es la muchedumbre indígena anónima la que sin quererlo hace el coro (ibáquico?). Como en el navío de Fitzcarraldo, el coro no deja de tener algo de pretensión de obra de arte. Para Nietzsche, en esta fusión donde las jerarquías están abolidas, "el ser humano no es ya un artista, se ha convertido en una obra de arte" (Nietzsche, 2010: 195) ¿Es el subcomandante Marcos esta obra, un "ícono" o un "símbolo"? ¿O son los "artistas de la pluma" - no los guerrilleros - quienes en realidad se han convertido a sí mismos en la obra de arte, lejos de la mesura, el sosiego, la "apariencia" y el relegamiento de las emociones salvajes propios de Apolo, el dios escultor?

Junto con cierta estetización del lenguaje, con la aparición de un "estilo", en Marcos está una voluntad 
manifiesta de rechazo al lenguaje conceptual, algo que, según Luis E. de Santiago Guervós, también es propio de Nietzsche. Para éste:

[...] las armas que uno tiene a mano no deben ser sólo adecuadas, sino también bellas; no sirven sólo para vencer, sino para vencer con "elegancia": esto es una exigencia de un pueblo agonal. Además de la impresión de "sinceridad", hay que producir también la impresión de superioridad en la libertad, la dignidad, la belleza, la forma de combate (Nietzsche, 2000: 99).

En su búsqueda de una dimensión estética, según De Santiago Guervós, "Nietzsche parte de una desconfianza generalizada hacia los aspectos conceptuales del pensamiento y rechaza categóricamente la mediación de los conceptos" (De Santiago, 2004: 369). Frente a este pensamiento conceptual está el arte, que:

[...] se eleva a "órgano de conocimiento", pues la naturaleza necesita del artista con vistas a su propia ilustración; [...] el arte no es conocimiento de objetos, conocimiento discursivo, sino conocimiento intuitivo. En él acontece la verdad en medio del aparecer. Desde esta nueva perspectiva, conocer se entiende como un comportarse estéticamente. Y en este sentido, sólo el arte puede aspirar a la verdad, pues el arte es más poderoso que el conocimiento, pues él quiere la vida (De Santiago, 2004: 376).

Muchos, de Elena Poniatowska a Yvon Le Bot pasando por Carlos Monsiváis, le agradecerán al EZLN el rechazo al pensamiento conceptual, y al subcomandante Marcos que no se exprese con análisis ni con "mediación de conceptos". Pareciera que lo que Marcos hace es expresarse y "aparecer" con naturalidad. Asílo considera Elena Poniatowska, al unísono con un Monsiváis que le reprocha "sectarismo" al primer EZLN, al referirse a "ese hombre que tiene un dios adentro y se llama Marcos" (EZLN, 2000: 324). Dice la escritora: “QQué lejos está Marcos de la vieja retórica de la izquierda mexicana! No habla de imperialismo yanqui o de la burguesía, no aburre con esa cantinela, sus palabras son nuevas, son jóvenes, se mueven, avanzan, salen del fuego de su pecho" (EZLN, 2000: 324-325).

Poco parece importar que desde muy pronto el EZLN vaya un poco a la deriva, pese a las múltiples simpatías obtenidas:

[...] mucho del impacto de la rebelión — constata relativamente temprano Antonio García de León - se ha diluido ante la ausencia de un proyecto político que esté a la altura de los tiempos que vivimos, al nivel de esta insólita insurgencia civil y de este florecimiento de la soberanía popular a lo largo y ancho del país (EZLN, 1998: 18).

Luego de que Marcos reconozca que en los orígenes hubo en el EZLN influencias desde maoísta hasta trotskista, es Le Bot quien saca la conclusión sobre otra novedad: "el discurso y las prácticas leninistas dejaron el lugar a la insurrección social y moral”, considera Le Bot (1997: 73). El nuevo referente está no en experiencias previas, sino en el mundo mítico:

[...] el modelo insurgente a la mexicana y la base comunitaria indígena llevaron a Zapata más allá del vanguardismo leninista o guevarista. La referencia central es la de Votán-Zapata, sincretismo de dos figuras tutelares que tienen en común la defensa de las tierras de las comunidades (Le Bot, 1997: 74).

Adolfo Gilly también se entusiasma por el recurso a "la comunidad como mito" en el EZLN, algo que para este autor sería típico de la izquierda (Gilly, 1998: 110).

Lo que atrae a parte de la intelectualidad es la creencia en una supuesta naturalidad de la palabra, renuente al concepto pero que expresa el sentimiento. Aunque Nietzsche se refiere a pueblos como el de la Grecia antigua, también puede pensarse no en el indígena chiapaneco, sino en la intelectualidad: "la retórica se enraíza en un pueblo que todavía vive entre imágenes míticas y que no conoce aún la necesidad absoluta de la fe histórica; ellos prefieren ser más bien persuadidos que instruidos" (Nietzsche, 2000: 81). Mientras que los miembros del EZLN han 
recibido instrucción política y militar, tal vez entre la intelectualidad se prefiere al verdadero aprendizaje político el persuadir y el ser persuadido. En todo caso, he aquí parte de lo que, por ejemplo, Carlos Monsiváis valora en el EZLN:

[...] esto suena un tanto romántico, y así se leen muchísimos textos de Marcos, pero sin el énfasis lírico el movimiento zapatista no habría reconocido otra dimensión, la estética, la relacionada con la nobleza de sentimiento [...] Al convertirse la decisión de sacrificio en voluntad de permanencia ocurre un fenómeno notorio: la estética un tanto convencional de los héroes muertos se transforma en el horizonte racional de los militantes vivos (EZLN, 2003: 21).

Es impresionante el registro, la potencia verbal. A veces es desmedido, injusto, cursi, con frecuencia es repetitivo, en ocasiones el antiguo sectarismo se filtra pero nunca lo avasalla. Siempre, es el interlocutor múltiple y muy inteligente (EZLN, 2003: 13-14).

Nietzsche siguió un recorrido similar después de El nacimiento de la tragedia, al volcarse al estudio de la retórica, luego de haber pasado por la música de Wagner. Para Yvon Le Bot, la palabra de Marcos no es sólo política: “[...] Marcos, además de jefe militar, es el intérprete, el portavoz de los indígenas levantados en armas, el inventor de una palabra político-poética irreductible para las estrategias de dominación, inaprensible para el aparato de poder" (Le Bot, 1997: 18). De Santiago Guervós escribe:

No hay que extrañarse de que Nietzsche vea en la retórica un verdadero poder: el poder de la palabra que se consideraba entre los griegos la prerrogativa más alta. Un ejemplo claro lo tenemos en Gorgias, que basaba su filosofía en un modelo retórico del lenguaje, y concedía a la palabra un extraordinario poder, un poder casi mágico y medicinal. El poder dominador del lenguaje hablado da al arte retórico un poder directo sobre las cosas humanas, puesto que, como decía el propio Isócrates, la palabra es 'señora y maestra' de todo lo que hacemos y pensamos. Esa conciencia de la omnipotencia de la palabra prevaleció antiguamente de un modo que a veces nos resulta hoy difícil de comprender. De ahí que Nietzsche considere el papel atribuido por los griegos a la retórica: la creencia de que todo depende de la representación que da de ello el poder de la palabra. Esa fuerza o poder se legitima genealógicamente por el hecho de que la retórica surge normalmente del subsuelo de un pueblo, especialmente a través de la conciencia mítica [...] lo que sugiere Nietzsche es que los griegos practicaron el mythos o la palabra mítica, y que realmente fue esta práctica la que les predispuso para la retórica (De Santiago, 2000: 26-27).

Más que en ícono o símbolo, el subcomandante Marcos tiende por momentos a verse convertido en mito. El asunto no está en Marcos, aunque sí en parte en una retórica siempre dirigida a una audiencia muy particular: la misma audiencia para la cual, salvo excepciones, el mundo indígena, antes que real, contradictorio y humano, es justamente un mundo a la vez natural y mítico, ese "subsuelo de un pueblo" del que únicamente se puede hablar con elocuencia y como si tuviera, por fuerza y siempre, algo mágico.

\section{Una guerrilla con "narrativa"}

Tanto los comunicados del EZLN como las palabras del subcomandante Marcos suelen acercarse a lo que en inglés se llama story, y que va desde el cuento hasta la historia, pasando por la trama, el argumento y el relato. La guerrilla se dirige con este medio a un público que se supone culto, aunque en realidad éste parece preferir la simpleza de lo aparentemente natural. Según Charles Tilly, las stories, que no excluyen la retórica (2006: 73), "dan cuenta simplificada de las relaciones de causa a efecto, de eventos desconcertantes, inesperados, dramáticos, problemáticos o ejemplares" (2006: 64), descartando entonces errores, consecuencias inesperadas, causas varias, etcétera, como si se tratara de obviar estas "complicaciones" (2006: 65). 
Según Hayden White, la narratividad da ni más ni menos que una "imagen de la vida": "[...] este valor atribuido a la narratividad en la representación de los acontecimientos reales surge del deseo de que los acontecimientos reales revelen la coherencia, integridad, plenitud, y cierre de una imagen de la vida que es y sólo puede ser imaginaria" (White, 1992: 38). Una imagen de una vida natural es lo que más de uno puede imaginarse en Chiapas, como escribe White:

La narrativa histórica, frente a la crónica, nos revela un mundo supuestamente finito, acabado, concluso, pero aún no disuelto, no desintegrado. En este mundo, la realidad lleva la máscara de un significado, cuya integridad y plenitud solo podemos imaginar, no experimentar. En la medida en que los relatos históricos pueden completarse, que pueden recibir un cierre narrativo, o que puede suponérseles una trama, le dan realidad al aroma de lo ideal (White 1992: 35).

Esa vida natural en "algún lugar de las montañas del sureste" tiene tal vez algo de ideal. Para White, en todo caso, no hay una narrativa neutral sobre acontecimientos reales o imaginarios:

[...] la narrativa es la expresión en el discurso de una forma particular de experimentar y de pensar el mundo, sus estructuras y sus procesos. De hecho, la milenaria vinculación del modo narrativo del discurso con el pensamiento mítico y religioso, por una parte, y con la ficción literaria, por la otra, fue lo que condujo a la condena de la historia narrativa por considerársela una manifestación de pensamiento mítico en la reflexión histórica (White, 2011: 471).

Otra condena vino de Braudel y de Barthes, para quienes la narrativa constituía un "espectáculo" y tenía algo de "producción teatral" (White, 2011: 472). Frente al mundo indígena, la mitificación con un trasfondo religioso puede ser tentadora, lo que explicaría la ausencia de una parte de la sociedad mexicana, a la que esa misma mitificación puede haber dicho poco. Frente a lo supuestamente "natural" de la guerrilla, como si fuese incluso una "erupción natural", lo teatral puede estar en la artificialidad — también supuesta- del intelectual, que puede querer deshacerse de ésta con una puesta en escena, la de la "autenticidad", que el indígena seguramente desconoce.

Si White se refiere al "imaginario" en términos lacanianos - lo que dice hacer-, lo cierto es que el subcomandante Marcos habrá de terminar en un juego de espejos, de imágenes. Le Bot lo expresa así: "el pasamontañas es un espejo para que los mexicanos ('tome el espejo y mírese') se descubran, [...] Un espejo que llama al país a interrogarse a sí mismo sobre su porvenir, a reconstruirse, a reinventarse" (Le Bot, 1997: 16). Por su parte, Gilly considera:

Ese espejo es ambiguo. Cada uno puede ver en él su propio rostro y creer que la rebelión habla de él mismo y de sus ideas o esperanzas y así acunarse en la ilusión y en el consuelo. Cada uno puede entonces imaginar que democracia e igualdad reinan en las comunidades agrarias, ignorar su carácter jerárquico y autoritario por necesidad y naturaleza y soñar una nueva edad de oro para uso personal o colectivo (Gilly, 1998: 111).

Alguien se lo dirá en Chiapas tal vez sin ninguna ironía al escritor uruguayo Eduardo Galeano: "detrás de estos pasamontañas estamos ustedes" (subcomandante Marcos, 2000: 10). El EZLN también valora esta curiosa imagen del espejo, según estas líneas citadas por Monsiváis:

[...] hermano, hermana indígena y no indígena: un espejo somos. Aquí estamos para vernos y mostrarnos, para que tú nos mires, para que tú te mires, para que el otro se mire a la mirada de nosotros. Aquí estamos, y un espejo somos. No la realidad, sino apenas un reflejo. No la luz, sino apenas un destello" (EZLN, 2003: 42).

¿No podría decir lo mismo de sí misma una parte de la intelectualidad de izquierda, salvo excepciones? ¿Por qué hay una "puesta en escena"? Porque siguiendo a White, "los narradores, por lo general (aunque no siempre), traman los acontecimientos de los que hablan" 
(White, 20ll: 483), y puede ser que el eco del EZLN y su líder respondan a una trama, como forma de organizar la narrativa, que no está en Chiapas. Escribe White: "En otras palabras, los narradores históricos a menudo aducen encontrar en los acontecimientos de los que hablan las formas de una u otra estructura de la trama de esas que solemos hallar en los distintos géneros de la ficción artística: el mito, la fábula y la leyenda" (White, 2011: 483). ¿Quién convierte en leyenda a quién en un encuentro como el del "Aguascalientes"?

Marcos explora el cuento con los relatos sobre el Viejo Antonio o sobre Don Durito de la Lacandona, de los que no nos ocuparemos aquí, aunque apelan a una imaginación muy peculiar, hasta donde el subcomandante Marcos pareciera querer manejar cierto lugar común: el del ancestro sabio de pueblo, como indígena mejor. En todo caso, escribe White: “cómo debe ser configurada una situación histórica dada depende de la sutileza del historiador para relacionar una estructura de trama específica con un conjunto de acontecimientos históricos a los que desea dotar de un tipo especial de significado" (White, 2003:115). Cabe insistir en la omnipresencia de la naturaleza y en el querer mostrar en la sabiduría ancestral —itambién natural? — "otra lógica", de todos modos con un sentido moralizante. Escribe White: "Otra forma con la que damos sentido a un conjunto de acontecimientos que parece extraño, enigmático o misterioso en sus manifestaciones inmediatas se basa en codificar el conjunto en términos de categorías provistas culturalmente, tales como conceptos metafísicos, creencias religiosas o formas de relato" (White, 2003: 116). Marcos descubre una forma de relato que se aviene bien a otro señalamiento de White: "donde, en una descripción de la realidad está presente la narrativa, podemos estar seguros de que también está presente la moralidad o el impulso moralizante" (White, 1992: 38).

El mundo indígena y chiapaneco se convierte por momentos en lo que otros quieran imaginarse a través de las palabras, la retórica y los cuentos del subcomandante Marcos y los comunicados del Comité Clandestino Revolucionario Indígena (CCRI), cuyas palabras suele redactar el mismo Marcos. Según White: "la antigua distinción entre ficción e historia, en la que la ficción se concibe como la representación de lo imaginable y la historia como la representación de lo real, debe dejar lugar al reconocimiento de que sólo podemos conocer lo real contrastándolo o asemejándolo a lo imaginable" (White, 2003:137). ¿Qué se imagina Marcos del mundo intelectual y qué se imagina éste de Chiapas? El EZLN y Marcos han logrado ser lo que otros se imaginan que son. Hay más, según White:

\section{[...] la metáfora no refleja la cosa que busca caracterizar, brinda direcciones para encontrar el conjunto de imágenes que se pretende asociar con ésta. Funciona como un símbolo, más que como un signo; lo que quiere decir no nos da una descripción o un ícono de la cosa que representa, pero nos dice qué imágenes buscar en nuestra experiencia cultural codificada en pos de determinar cómo nos deberíamos sentir acerca de la cosa representada (White, 2003: 126).}

Después de destacar el poder que desde un principio adquieren la imagen y la palabra en el accionar del EZLN dando lugar a una disputa por espacios simbólicos y discursivos (Gilly,1998: 92), Gilly constata "desplazamientos entre racionalidades" en los discursos de Marcos y el EZLN que "[...] suelen ser desconcertantes para el interlocutor no advertido", pero que "[...] produce(n) un efecto de ambigüedad buscada [romántico, una vez más] que protege al emisor, desconcierta al receptor hostil y deja al receptor amigo la posibilidad de múltiples interpretaciones, es decir, de ajustar el significado a su deseo" (Gilly, 1998: 107). ¿Qué hay en el EZLN? Insistamos: lo que cualquiera quiera encontrar, aunque difícilmente voces propias de los indígenas. A partir de cierto momento los indígenas en armas van dejando de ser reales y pasan a ser lo que otros quieren imaginarse y creen sentir que aquéllos son. Marcos parece, por su parte, amoldarse de distintas formas a esta imagen y este sentir, mientras en la dimensión real la capacidad de convocatoria del EZLN tiende a perderse.

Siguiendo a Northrop Frye, White sostiene que: “[...] la narrativa histórica apunta simultáneamente en 
dos direcciones: hacia los acontecimientos descritos en la narrativa y hacia el tipo de relato o mythos que el historiador ha elegido como ícono de la estructura de los acontecimientos" (White, 2003: 120). Gilly reconoce que a través de Marcos pareciera hablar el mito y que hay en todo caso algo mágico. Refiriéndose a las palabras del EZLN, señala este autor que:

[...] la voz continúa hablando entre la religión y el mito, el agravio y el orgullo, el ruego y la comunión [...] Este discurso habla desde el imaginario y los valores del mundo encantado. Este mundo se prolonga y se reitera en los gestos y los símbolos enmascarados, guerreros, nieblas, selva, silencios, historias de noche y ceremonias nocturnas (Gilly, 1998: 106).

El mito se ha impuesto a los hechos, que terminan por ser desconocidos.

\section{Hacia el buen salvaje: el hombre silvestre}

La insurrección armada en Chiapas pareciera haber tenido su propia visión de lo que Roger Bartra llama el "hombre silvestre" que habría inspirado a Jean-Jacques Rousseau. El escritor portugués José Saramago lo había intuido: reducido el problema de Chiapas a la cuestión del "ser indígena", cabía preguntarse con ironía, como alguna vez lo hiciera Montesquieu: icómo se puede ser persa? Saramago no perdió la oportunidad de criticar al "occidental de mentalidad", para señalar acto seguido:

[...] ser "persa" es ser el extraño, es ser el diferente, es, en una palabra, ser "otro". La simple existencia de ser "persa" ha sido suficiente para incomodar, confundir, desorganizar, perturbar la mecánica de las instituciones, el "persa" puede llegar hasta el extremo inadmisible de desasosegar aquello de lo que todos los gobiernos del mundo son más celosos, la soberana tranquilidad de su poder (Subcomandante Marcos, 2001: 22).

Saramago enumera a indígenas de Brasil, de Estados Unidos o de los Andes como si el poder pudiera verse cuestionado desde una otredad o alteridad que en realidad ya fue planteada alguna vez en espejo del mundo occidental, con el fin de oponer el mundo natural al de la política y la cultura, y viceversa. Saramago escribe:

[...] como escribió un día esa figura, por muchos motivos excepcional y ejemplar, bajo el nombre de subcomandante insurgente Marcos, 'un mundo donde quepan muchos mundos, un mundo que sea uno y diverso', un mundo que, me permito añadir, para siempre jamás, declarase intocable el derecho de cada cual a ser "persa" durante el tiempo que quisiera, y no obedeciendo nada más que a sus propias razones (Saramago, 2001: 25).

Esto sería en otra época el equivalente del derecho del hombre salvaje - bueno o malo- a reivindicarse en su "salvajismo".

Para Bartra, este "hombre salvaje" suele ser una construcción europea y lo es en todo caso en Rousseau, quien al describir a aquél no podría sino estar describiendo en realidad una parte de sí mismo. Si se quiere, lo que expresa el subcomandante Marcos -no así el EZLN - es una parte del "sí mismo" de la intelectualidad ya mencionada que, lejos de regocijarse en la otredad, lo hace en la identidad. Para Bartra, Rousseau termina construyendo en sus contradicciones "ciudadanos de la naturaleza". En realidad, entre cultura y naturaleza, entre política y naturaleza, Rousseau deja atrás en ambos casos a la segunda. En cambio, frente al EZLN - y no frente al subcomandante Marcos-, la dirección es la contraria: la "verdadera cultura" pareciera estar en una especie de "naturaleza virgen", incluida la "naturaleza humana" - iinalterada en quinientos años? - de tal modo que se rechaza la cultura por artificial —es una construcción humana-y se prefiere "lo natural", y no pasará mucho tiempo antes de que se olvide que el EZLN es una construcción política y militar. Galeano lo ve así:

[...] la niebla es el pasamontañas que usa la selva. Así ella oculta a sus hijos perseguidos. De la niebla salen, 
a la niebla vuelven [...] Estos príncipes, condenados a la servidumbre, fueron los primeros y son los últimos. Les han arrancado la tierra, les han negado la palabra, les han prohibido la memoria; pero ellos han sabido refugiarse en la niebla, en el misterio, y de allí han salido, enmascarados, para desenmascarar el poder que los humilla (Galeano, 2000: 10).

La intelectualidad que admira a Marcos y al EZLN opone a la cultura, tal vez citadina y cortesana al mismo tiempo, y a una política corrupta, algo así como un "buen salvaje" que permite reivindicar el iusnaturalismo que, en cambio, Rousseau rechaza. Éste parecía haber partido de un ideal del hombre silvestre (homo sylvestris), bueno y noble. En Vincennes, camino a ver a Diderot, Rousseau parece tener una iluminación:

!Oh señor! Si hubiese podido escribir una cuarta parte de lo que vi y sentí bajo ese árbol, con cuánta claridad hubiera hecho ver todas las contradicciones del sistema social, con qué fuerza hubiera expuesto todos los abusos de nuestras instituciones, con qué simplicidad habría demostrado que el hombre es bueno por naturaleza y sólo se vuelve malo merced a las instituciones (Rousseau, 2008: 220).

Aquí en realidad no hay hombre salvaje, ni europeo ni americano: Rousseau habla de la naturaleza humana, una naturaleza humana "primera". Rousseau no idealiza este estado de naturaleza, según se desprende de la primera versión del Contrato social. Por sorprendente que parezca, Rousseau escribe:

Así la dulce voz de la naturaleza no es ya para nosotros una guía infalible, ni la independencia de la misma un estado deseable. Hemos perdido la paz y la inocencia para siempre antes de haber podido gustar sus delicias. Insensible para los hombres rudos de la primera época, fugitiva para los hombres ilustrados de la época posterior, la vida feliz de la edad de oro fue siempre un estado ajeno a la raza humana, o bien porque la desconoció cuando pudo gozarla, o bien porque la perdió cuando pudo conocerla (Rousseau, 2000: 335).
Ni siquiera es necesario ir tan lejos: previo a su Discurso sobre el origen y los fundamentos de la desigualdad entre los hombres, Rousseau escribe que:

[...] no es liviana empresa separar lo que hay de originario y de artificial en la naturaleza actual del hombre, ni conocer bien un estado que ya no existe, que quizá no haya existido, que probablemente no existirá jamás, y del que sin embargo es necesario tener nociones precisas para juzgar bien nuestro estado presente (Rousseau, 1996: 195).

Más allá del presupuesto de la bondad natural del hombre, no hay en Rousseau - quien difícilmente estaría hablando aquí de su propia naturalezaidealización de algún paraíso perdido. "Plena armonía" tampoco existía en el mundo maya antes de la llegada de los españoles. No habría una "naturaleza indígena caída”, alguna vez inocente y buena. En un principio, Marcos y el EZLN reivindican el derecho del indígena a la ciudadanía plena que efectivamente le ha sido negada. Marcos afirma: "Y nosotros aspiramos a convertirnos en ciudadanos como los demás, queremos formar parte de México y eso sin perder nuestras particularidades, sin estar obligados a renunciar a nuestra cultura, en definitiva, sin dejar de ser indígenas" (Ramonet, 2001: 29). El EZLN reivindica así su entrada en el quehacer ciudadano, y en cierto modo lo logrará al presentarse los indígenas en el Congreso al comienzo del sexenio foxista. Es sobre todo el subcomandante Marcos quien no parece dudar en darse carta de ciudadanía y a quien no le es negada. Con el EZLN en su conjunto pasa otra cosa, ya que permanece como "coro báquico" sin personalidad propia — salvo parcialmente con Tacho y Moisés-, cuando no confundido con el paisaje cual telón de fondo. Escribe Marcos: "somos y seremos uno más en la marcha, la de la Dignidad Indígena, la del Color de la Tierra [...]" Para Monsiváis esto es retórica, aunque le atribuye, quizás erróneamente, un "origen indígena" (EZLN, 2003: 42).

En su Discurso, Rousseau pinta a un hombre natural que para Bartra es un "salvaje piadoso de corazón tierno” (Bartra, 1997: 295). Este autor podría estar 
simplificando: el ginebrino escribe que este salvaje es perfectible y, además, que es libre, ambas cosas pasadas por alto en la caricatura de Bartra. Así, la entrada en la cultura y la política supondría entonces a la vez la educación, que difícilmente termina — si es que esa naturaleza humana no deja nunca de ser perfectibley el ejercicio de la libertad. En realidad, antes que un ciudadano de la naturaleza está la potencial naturaleza del ciudadano, perfectible, pero también corruptible. El salto que quienes aspiran a cierta tutela sobre el EZLN no dan es el que va de la primera a la segunda parte del Discurso, puesto que en éste no hay ninguna "sociedad civil natural" - contra un "Estado artificial"-, ni exenta de conflicto, en particular por la existencia de la propiedad, puesto que esa sociedad civil, con toda su violencia, comienza, según Rousseau, cuando alguien dice: "esto me pertenece". Bartra termina concluyendo con todo:

[...] es evidente que Rousseau rompe con la tradición jusnaturalista que, a partir del estado de naturaleza, establece los derechos innatos del hombre, anteriores a la sociedad civil e independientes de ella. Rousseau no extrae principios morales derivados de la condición natural del hombre; la legitimidad de una nueva sociedad civil no puede fundarse ni en la oposición al mal originario representado por el salvaje hobbesiano (o por el pecado de Adán y Eva), ni por la defensa de una bondad fundamentalmente simbolizada por el salvaje noble; la legitimidad, en la perspectiva de Rousseau, es necesario construirla, y su homme sauvage sirve como impulso a la actitud crítica, pero no es un modelo a seguir [...] De aquí podría concluirse que hay en el pensamiento de Rousseau una primacía de la política - y por extensión, de la historia - sobre la moral, lo que nos permitiría hacer a un lado la idea de que fue el precursor del yo romántico (Bartra,1997: 311).

Es a contrapelo de esta formación para la política como va a veces la narrativa intelectual sobre el EZLN, que por lo demás casi nunca toma en cuenta los trabajos sobre la historia del estado y los indígenas que habitan en él.

\section{Conclusiones}

Al final de un periplo de casi dos décadas sobrevivió en el EZLN, de manera digna y merecedora de respeto, pese al olvido citadino/intelectual, lo que pudo organizarse, lo que es tanto como decir lo que se alejó de lo natural, desde las Juntas de Buen Gobierno en los Caracoles, hasta la Escuelita Zapatista. No son cuestiones de detalle ni es esta mención una "concesión": con el antecedente de los MAREZ (Municipios Autónomos Rebeldes Zapatistas) desde 1994, pasado el gran interés de buena parte de la intelectualidad en los años noventa - con excepciones como las de Pablo González Casanova (2003) o Gilberto López y Rivas, por ejemplo - se produjo un viraje organizativo importante que relativizó la influencia militar y no gubernamental (Baronnet, Mora y Stahler-Sholk, 2012a: 25) entre los indígenas, contra lo que sugerían tesis como por ejemplo las de Marco Estrada, no tan desencaminadas, con todo, sobre el control militar de larga data de la organización política (Estrada, 2007). Sucedió en 2003 con las JBG, las cuales ayudaron en la maduración de la autonomía práctica y en las "representaciones", por ejemplo femeninas. Esto tuvo lugar, entre otras, en dos direcciones importantes: contra el añejo corporativismo del Partido Revolucionario Institucional y contra la tentación de conjugar acaparamiento de puestos e intereses materiales, algo imposible, por ejemplo, al ser los promotores de educación o salud nombrados por asambleas (Baronnet, Mora, Stahler-Sholk, 2012b: 520). Alejandro Cerda García ha descrito ese corporativismo, de origen cardenista, como un intercambio de beneficios - dotaciones de tierras a cambio de apoyo político a las autoridades en turno(Cerda, 20ll: 12) que de algún modo terminó cargado de "etnicismo" - evolucionismo, relativismo cultural一, con la sacralización de lo indígena por oponerse a "lo occidental" y, por ende, a la "nación mexicana", y que tuvo como otra cara la "folclorización" del mundo indígena, aunque sin verdadero acceso al espacio público, ya en el neoindigenismo/multiculturalimo neoliberal (Cerda, 2011: 47). Del mismo modo en que a partir de las decisiones de 2003 a 2005 el EZLN fue 
desapareciendo de un "escenario" en más de un sentido etnicista y paternalista - io incluso maternalista?Marcos, convertido en pleno agotamiento en "Delegado Zero", pudo dirigirse en la larga gira de la Otra Campaña sobre todo a un mundo indígena en algunos lugares más olvidado incluso que el chiapaneco, pero insistamos en que sin gran eco en la mayor parte de la intelectualidad, ni siquiera en aquella que reclamaba "mayor voz indígena”. Así, a partir del análisis - lo hay en la Sexta Declaración de la Selva Lacandona- y de la presencia en la Otra Campaña de distintas comunidades indígenas del territorio mexicano, de gran diversidad, el EZLN dejó de interesar a los segmentos ya mencionados, que se volcaron hacia otras cosas y tal vez nuevas promesas de poder.

Según Shannan L. Mattiace: “[...] el EZLN y el movimiento indígena nacional proponen un proyecto nacional alternativo, cuyo centro consiste en las movilizaciones de las bases. En este proyecto, la incorporación a la nación no es algo que viene 'desde arriba', como sucede en el sistema corporativista de representación, sino 'desde abajo'" (Mattiace, 2003: 233). iInteresa a la intelectualidad mencionada y a parte de la sociedad civil "mandar obedeciendo" y no aprovecharse de posiciones jerárquicas —en la academia, por ejemplo, dicho sea con ironía-y cambiar prácticas de existencia social aprendiendo de los indígenas "desde abajo", más allá de observar desde lo alto de "la neutralidad" supuestamente científica, confundida con imparcialidad? No parece haber sido el caso. Desde el momento en que se planteó en la práctica gobernar "desde abajo" dejó de haber una "narrativa del EZLN" en la que cada quien pudiera encontrar alguno de sus deseos. Sobrevivió al final la política con la capacidad de algunas comunidades indígenas chiapanecas para autoorganizarse sin mayores tutelas. El silencio citadino ha sido aquí tan sorprendente como en su momento lo fue el ruido ante la guerrilla festiva, "caótica" y "natural".

A juzgar por una entrevista con Ignacio Ramonet en la cual Marcos se explaya sobre el lugar de la imagen en el mundo actual y sobre lo que es dado esperar de un intelectual - y que "por algo" no ocurre siempre en el mundo actual-, no parece que no haya comprendido, incluyendo una ecuación básica, y crítica, de Régis Debray (Ramonet, 2001: 77) que dice mucho: lo visible=lo real=lo verdadero. Debray tal vez "por algo" haya pedido que el líder del EZLN no usara pasamontañas: ¿Marcos creó una imagen? Como hemos señalado, hay muchos problemas del mundo actual que no parecen habérseles escapado ni a Marcos ni al EZLN, salvo en un punto: la probable dificultad de parte de la intelectualidad de izquierda y de la sociedad civil para percibir más allá de una imagen que no hay nada de natural, ni de virgen, en el indígena ni en quien lo representa. La insurrección no fue algo que "debía ocurrir", aunque resultó espectacularizada, retomada y hasta cierto punto neutralizada por más de un interlocutor del EZLN.

\section{Referencias bibliográficas}

Baronnet, Bruno, Mariana Mora Bayo y Richard StahlerSholk (2012a). "Introducción". Reflexiones sobre procesos en marcha”. En Bruno Baronnet, Mariana Mora Bayo y Richard Sthler-Sholk (coords.), Luchas 'muy otras'. Zapatismo y autonomía en las comunidades indígenas de Chiapas. México: Universidad Autónoma Metropolitana Xochimilco, Centro de Investigaciones y Estudios Superiores en Antropología Social, Universidad Autónoma de Chiapas, pp. 19-53.

Baronnet, Bruno, Mariana Mora Bayo y Richard Stahler-Sholk (2012b). "Conclusiones. Luchas 'muy otras'. Reflexiones sobre procesos en marcha”. En Bruno Baronnet, Mariana Mora Bayo y Richard Sthler-Sholk (coords.), Luchas 'muy otras'. Zapatismo y autonomía en las comunidades indígenas de Chiapas. México: Universidad Autónoma Metropolitana Xochimilco, Centro de Investigaciones y Estudios Superiores en Antropología Social, Universidad Autónoma de Chiapas, pp. 517-529.

Bartra, Roger (1997), El salvaje artificial. Barcelona: Destino. Cerda García, Alejandro (2011). Imaginando zapatismo. Multiculturalidad y autonomía indígena en Chiapas desde un municipio autónomo. México: Porrúa/Universidad Autónoma Metropolitana. 
De Santiago Guervós, Luis E (2004). Arte y poder. Aproximación a la estética de Nietzsche. Madrid: Trotta.

Estrada, Marco (2007). La comunidad armada rebelde y el EZLN: un estudio histórico y sociológico sobre las bases de apoyo zapatistas en las cañadas tojolabales de la Selva Lacandona, México: El Colegio de México.

EZLN (1998). Documentos y comunicados, t. 3. México: Era.

EZLN (2000). Documentos y comunicados, t. 1. México: Era.

EZLN (2003). Documentos y comunicados, t. -5 México: Era.

Gilly, Adolfo (1998). Chiapas. La razón ardiente. México: Era.

Gonzalez Casanova, Pablo (2003). "Los Caracoles zapatistas: redes de resistencia y autonomía". En OSAL (Observatorio Social de América Latina), mayoagosto, Buenos Aires: CLACSO, pp. 15-30.

Harvey, Neil (2000). La rebelión de Chiapas. La lucha por la tierra y la democracia. México: ERA.

Le Bot, Yvon (1997). Subcomandante Marcos. El sueño zapatista. Barcelona: Plaza \& Janés.

Leyva, Xóchitl y Willibald Sonnleitner (2000), “¿Qué es el neozapatismo?" En Espiral, vol. VI, no. 17, abril, Universidad de Guadalajara, Guadalajara, México.

Mattiace, Shannan L. (2003). To See with Two Eyes: Peasant Activism o Indian Autonomy in Chiapas, Mexico. Albuquerque: University of New Mexico Press.

Nietzsche, Friedrich (2000). Escritos sobre retórica, Madrid: Trotta.

Nietzsche, Federico (2010). El nacimiento de la tragedia. México: Grupo Editorial Tomo.

Pérez Uribe, Matilde (1994), "Se reanudan los enfrentamientos en Ocosingo entre fuerzas del Ejército y los sublevados". En La Jornada, 4 de enero, p. 7.
Poniatowska, Elena (1994a). "Iglesia y ONGs llenaron el vacío gubernamental, afirma Marcos”. En La Jornada, 3 de agosto. México, p. 13.

Poniatowska, Elena (1994b), "Si sólo fuera cosa de Marcos, el EZLN ya hubiera tronado", La Jornada, 31 de julio. México, pp. 1 y 18.

Ramonet, Ignacio (2001). Marcos, la dignidad rebelde, Buenos Aires: Le Monde Diplomatique/El Dipló.

Rousseau, Jean-Jacques (1996). Del contrato social. Sobre las ciencias y las artes. Sobre el origen y los fundamentos de la desigualdad entre los hombres. Madrid: Alianza.

Rousseau, Jean-Jacques (2000). "Del contrato social (primera versión, Manuscrito de Ginebra)". En Contrastes, Revista Interdisciplinar de Filosofía, vol. V. Málaga: Universidad de Málaga, pp. 313-330.

Rousseau, Jean Jacques (2008). Cartas morales y otra correspondencia. Madrid: Plaza y Valdés.

Subcomandante Marcos (2000). Detrás de nosotros estamos ustedes. México: Plaza \& Janes.

Subcomandante Marcos (2001). Escritos selectos. Nueva York: Seven Stories Press. Prólogo de José Saramago.

Tello Díaz, Carlos (1995). La rebelión de las cañadas. México: Cal y Arena.

Tilly, Charles (2006). Why? Princeton: Princeton University Press.

White, Hayden (1992). El contenido de la forma. Narrativa, discurso y representación histórica. Barcelona: Paidós.

White, Hayden (2003). El texto histórico como artefacto literario. Barcelona: Paidós.

White, Hayden (2011). La ficción de la narrativa. Ensayos sobre historia, literatura y teoría. 1957-2007. Buenos Aires: Eterna Cadencia Editora. 